\title{
Bubble Seeding Nanocavities: Multiple Polymer Foam Cell Nucleation by Polydimethylsiloxane-Grafted Designer Silica Nanoparticles
}

\author{
Shanqiu Liu, Sida Yin, Joost Duvigneau,* and G. Julius Vancso*
}

Cite This: ACS Nano 2020, 14, 1623-1634

Read Online

ACCESS 1

Џlll Metrics \& More

回国 Article Recommendations

Supporting Information

ABSTRACT: We describe a successful strategy to substantially enhance cell nucleation efficiency in polymer foams by using designer nanoparticles as nucleating agents. Bare and poly(dimethylsilane) (PDMS)-grafted raspberry-like silica nanoparticles with diameters ranging from $\sim 80 \mathrm{~nm}$ to $\sim 200 \mathrm{~nm}$ were synthesized and utilized as highly efficient cell nucleators in $\mathrm{CO}_{2}$-blown nanocellular polymethyl methacrylate (PMMA) foams. The successful synthesis of core-shell nanoparticles was confirmed by Fourier transform infrared spectroscopy, thermogravimetric analysis, Brunauer-Emmett-Teller measurements, and transmission electron microscopy. The cell size and cell density of the obtained PMMA micro- and nanocellular foams were determined by scanning electron microscopy. The results show that increased surface roughness enhances the nucleation efficiency of the designer silica particles. This effect is ascribed to a decreased

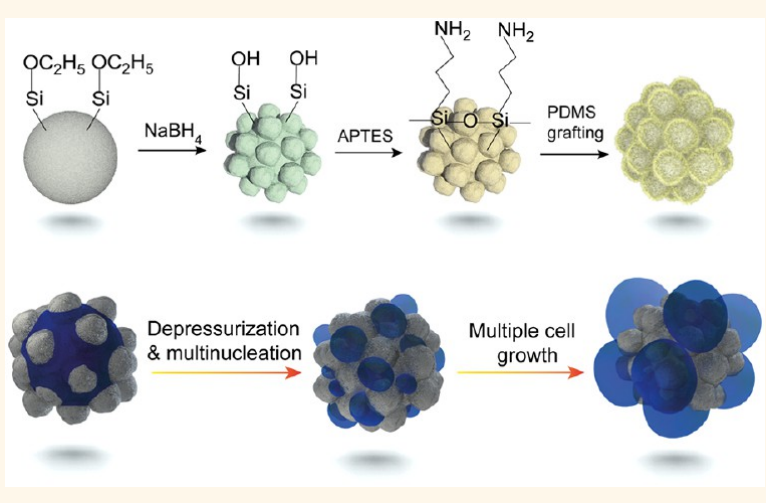
nucleation free energy for foam cell nucleation in the nanocavities at the melt-nucleator interface. For PDMS grafted raspberry-like silica nanoparticles with diameters of 155 and $200 \mathrm{~nm}$, multiple cell nucleation events were observed. These hybrid particles had nucleation efficiencies of 3.7 and 6.2, respectively. The surprising increase in nucleation efficiency to above unity is ascribed to the significant increase in $\mathrm{CO}_{2}$ absorption and capillary condensation in the corresponding PMMA during saturation. This increase results in the presence of large amounts of the physical blowing agent close to energetically favorable nucleation points. Additionally, it is shown that as a consequence of cell coalescence, the increased number of foam cells is rapidly reduced during the first seconds of foaming. Hence, the design of highly efficient nucleating particles, as well as careful selection of foam matrix materials, seems to be of pivotal importance for obtaining polymer cellular materials with cell dimensions at the nanoscale. These findings contribute to the fabrication of polymer foams with high thermal insulation capacity and have relevance in general to the area of cellular materials.

KEYWORDS: nanocellular materials, polymer foam, nanocavity, $\mathrm{CO}_{2}$ capillary condensation, core-shell nanoparticles

$\mathrm{N}$ anocellular polymer foams are receiving considerable attention from the scientific and industrial communities. $^{1-6}$ This interest is ascribed to the unexpected and sometimes exciting foam properties when their cells have diameters on the order of a few tens to hundreds of nanometers. For instance, the thermal conductivity of nanocellular foams is significantly reduced as a result of the Knudsen effect provided that the foam density is sufficiently low. ${ }^{2,7}$ In addition, compared to that of microcellular foams with similar densities, the mechanical performance of these foams in terms of, for example, the Young's modulus, impact properties and Shore hardness, is significantly improved. ${ }^{8-10}$ Thus, nanocellular polymer foams with low thermal con- ductivity can offer great alternative options when considering new classes of materials, for instance, to realize reductions in fuel consumption and $\mathrm{CO}_{2}$ emissions in transportation as well as to manage the thermal energy in buildings.

Nanocellular polymer foam structures can be obtained by various strategies, for example, selective extraction/decom-

Received: August 28, 2019

Accepted: January 31, 2020

Published: January 31, 2020 
position, ${ }^{11,12}$ templating/imprinting, ${ }^{13-15}$ chemical/physical foaming, ${ }^{8,16-20}$ etc. Among these methods, $\mathrm{CO}_{2}$-based batch foaming is of particular interest, which is ascribed to good control over the foaming conditions as well as to the low cost and environmental friendliness of $\mathrm{CO}_{2}$ as a physical blowing agent. ${ }^{9}$ In batch foaming, the polymer is first saturated with $\mathrm{CO}_{2}$ at a few to several hundreds of bars for a given time (on the order of hours to days). Subsequently, foaming is induced by a quick depressurization step that is typically followed by an increase in temperature. This results in an oversaturation of the dissolved $\mathrm{CO}_{2}$ in the polymer gas mixture leading to cell nucleation followed by rapid cell expansion. ${ }^{21}$ The disadvantage of batch foaming compared to other methods is that it has a relatively small batch size (i.e., on the scale of liters), which limits the industrial relevance of this process. On the other hand, nanocellular foam extrusion, that is, a continuous process, remains challenging, which is ascribed to the difficult control over key physical foaming parameters, for example, $\mathrm{CO}_{2}$ solubility, $\mathrm{CO}_{2}$ diffusivity, and foaming temperature. ${ }^{22-24}$

In addition to the production challenges, nanocellular foams with high porosities $(>85 \%)$ and cell densities $\left(>10^{14}\right.$ cells $\mathrm{cm}^{-3}$ ) have been rarely reported. ${ }^{4,25-27}$ This is ascribed to the fact that it is difficult to nucleate such high cell densities in the early stages of foaming. In addition, on the time scale of foaming, cell coalesce is hard to avoid. Frequently used strategies to increase the nucleated cell density rely on increasing the physical blowing agent saturation pressure and/or increasing the pressure release rate. ${ }^{3,25,28}$

The introduction of nanostructured heterogeneous phases to polymers as heterogeneous nucleation sites prior to foaming has also been considered a promising approach. Examples include the use of phase-separated block copolymer domains $^{29-32}$ and inorganic nanofillers. ${ }^{18,33-38}$

For instance, Rodriguez-Pérez and co-workers ${ }^{29}$ reported on $\mathrm{CO}_{2}$-assisted batch foaming of polymethyl methacrylate (PMMA) and poly(methyl methacrylate-block-butyl acrylateblock methyl methacrylate) (MAM) blends. The authors demonstrated that foam cells produced from these PMMA/ MAM blends were nucleated in the nanostructured MAM micellar phase, which is ascribed to the high $\mathrm{CO}_{2}$-philicity of the poly(butyl acrylate) phase compared to the PMMA matrix. McClurg and co-workers ${ }^{31}$ demonstrated that the incorporation of A-B diblock copolymers containing poly(dimethylsiloxane) as the core block into polystyrene prior to foaming increases the cell density of microcellular polystyrene foams. The nanostructured poly(dimethylsilane) (PDMS) domains were considered efficient nucleation sites because of their high $\mathrm{CO}_{2}$-philicity as well as the low surface energy of PDMS.

Compared to block copolymer micelles, silica nanoparticles are of particular interest for use as heterogeneous nucleation agents in polymer foaming because of their low cost and easy preparation and the simplicity of employing various surface decoration strategies. ${ }^{39,40}$ For instance, Zhai and co-workers ${ }^{37}$ demonstrated that the incorporation of silica nanoparticles into polycarbonate prior to foaming resulted in a higher cell density and more uniform cell size distribution than those in the polycarbonate foams containing no silica nanoparticles as nucleating agents. Yang and co-workers ${ }^{41}$ reported that the decoration of silica nanoparticles with $\mathrm{CO}_{2}$-philic poly(ionic liquid) significantly enhances cell nucleation in $\mathrm{CO}_{2}$-assisted polystyrene foaming compared to polystyrene foams prepared with bare silica nanoparticles as nucleating agents. Despite these promising results, we note that the nanoparticles utilized so far for nucleation have suffered from poor nucleation efficiencies; that is, the number of foam cells obtained per number of nanoparticles per $\mathrm{cm}^{3}$ added to the polymer matrix prior to foaming was small. The nucleation efficiencies for these inorganic particle-based nanofillers are typically far below $0.01 .^{18,41-43}$ This means that hundreds of added particles result in the formation of only one foam cell during foaming. In these calculations, it is assumed that homogeneous nucleation and cell coalescence can be neglected. ${ }^{3}$ We have reported the successful utilization of PDMS-grafted silica nanoparticles with a silica core diameter of $80 \mathrm{~nm}$ with a nucleation efficiency of approximately 0.5 for the preparation of $\mathrm{CO}_{2}$-blown batch PMMA foams. ${ }^{33}$ The good efficiency of these particles is ascribed to (i) the low surface energy of the PDMS shell, which reduces the nucleation energy barrier and (ii) the higher local $\mathrm{CO}_{2}$ concentration in the PDMS shell $(\sim 75 \text { wt } \%)^{44}$ than in the PMMA matrix $(\sim 18$ wt $\%) .{ }^{45}$ Furthermore, we demonstrated that the contribution of line tension significantly reduces the nucleation efficiency of PDMS-grafted nanoparticles with a silica core diameter below $40 \mathrm{~nm}$ under the used foaming conditions (i.e., $\mathrm{CO}_{2}$ saturation pressure of 55 bar and foaming at $\left.40{ }^{\circ} \mathrm{C}\right) .{ }^{33}$ Thus, the use of smaller particles, for example, particles $10 \mathrm{~nm}$ in diameter, is considered unfavorable, although it would in principle allow for the addition of the required high number of potential nucleation sites $\left(>10^{15} \mathrm{~cm}^{-3}\right)$ at relatively low weight percentages of particle loading. In fact, increasing the weight percentage of particle loading for particles with sufficiently large diameters $(>60 \mathrm{~nm})$ to incorporate the required number of potential nucleation sites renders the resulting particle-filled polymer matrix barely foamable. Thus, we conclude that enhanced particle designs are needed to increase the nucleation efficiency to unity and beyond.

The effect of surface roughness (e.g., nanocavities) on the free energy of heterogeneous foam cell nucleation has not been included in the particle design process until now. Yang and coworkers reported $^{46}$ a thermodynamic model and an analytical solution for the free energy of cell nucleation at the nanometer length scale in nanocavities. They showed that cells nucleated from a concave surface have a lower nucleation free energy than cells nucleated from flat convex surfaces (e.g., spherical particles). ${ }^{47,48}$ Inspired by these results, we considered surface roughness as an important and ignored design parameter for hybrid nucleating particle designs in enhanced nanocellular foaming. We chose a strategy to prepare silica nanoparticles with a superimposed roughened surface morphology. As the particles resemble a raspberry in appearance, we call them raspberry-like silica nanoparticles.

Since the preparation of raspberry-like silica nanoparticles is fairly easy and well described in the literature, ${ }^{49-53}$ we considered these surface roughened nanoparticles as ideal candidates to explore the effect of nanocavities on cell nucleation of nanocellular foams. For example, $\mathrm{He}$ and coworkers $^{51}$ reported on a method to produce raspberry-like nanoparticles by a self-templated etching route. This method limits the particle diameter to $60 \mathrm{~nm}$ or larger. In fact, for the purpose of this work, this size is acceptable since it allowed us to study the effect of particle surface roughness on foam cell nucleation without considering other effects, such as particle curvature. $^{43,54}$

Here, we show that raspberry-like silica nanoparticles are efficient foam cell nucleators with nucleation efficiencies that 
a

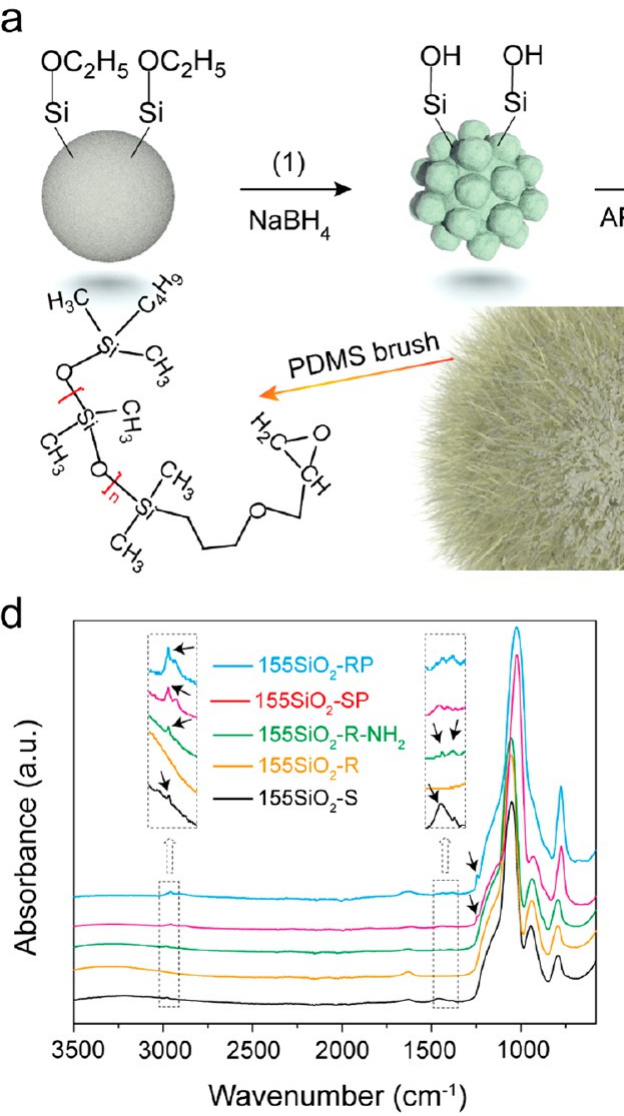

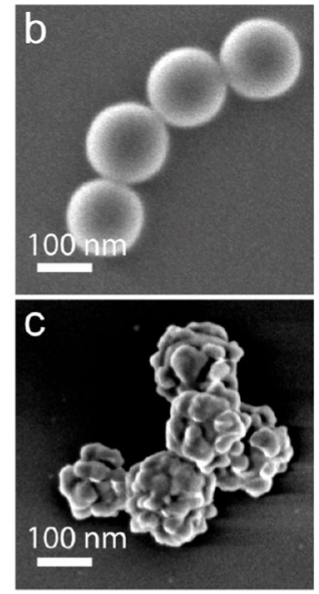

e

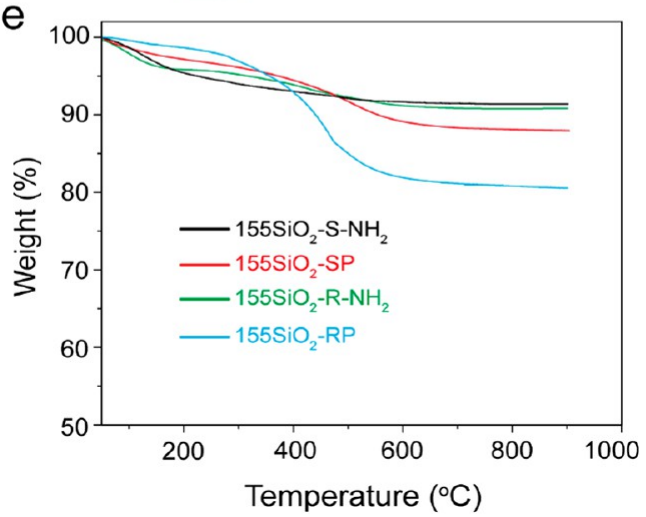

Figure 1. (a) A schematic of the $\mathrm{SiO}_{2}-\mathrm{RP}$ NP preparation process. In (b) and (c) $\mathrm{SEM}$ images of $\mathrm{SiO}_{2}-\mathrm{S}_{\text {and }} \mathrm{SiO}_{2}-\mathrm{R} \mathrm{NPs}$ with a silica particle diameter of $\sim 155 \mathrm{~nm}$ are shown, respectively. (d) Single reflection ATR-FTIR absorbance spectra of $155 \mathrm{SiO}_{2}-\mathrm{S}_{1} 155 \mathrm{SiO}_{2}-\mathrm{R}, 155 \mathrm{SiO}_{2}-\mathrm{R}$ $\mathrm{NH}_{2}, 155 \mathrm{SiO}_{2}-\mathrm{RP}$, and $155 \mathrm{SiO}_{2}$-SP NPs. The black arrows in the FTIR spectra indicate characteristic FTIR absorbance values of the (modified) silica NPs. (e) Non-isothermal TGA thermograms of the $155 \mathrm{SiO}_{2}-\mathrm{S}_{-} \mathrm{NH}_{2}, 155 \mathrm{SiO}_{2}-\mathrm{R}_{-} \mathrm{NH}_{2}, 155 \mathrm{SiO}{ }_{2}-\mathrm{SP}$, and $155 \mathrm{SiO}{ }_{2}-\mathrm{RP} \mathrm{NPs}$.

are comparable to their PDMS grafted nearly spherical counterparts. Upon decorating the raspberry-like silica nanoparticles with a few nanometer-thick PDMS shell, multiple foam cell nucleation events were observed from a single designer nanoparticle, and the highest nucleation efficiency obtained was 6.2 for particles with an overall core diameter of $\sim 200 \mathrm{~nm}$. This nucleation efficiency is nearly 40 times higher than that of a pristine nearly spherical silica nanoparticle with a similar diameter. We qualitatively show that the high nucleation efficiency obtained for PDMS-grafted raspberrylike silica nanoparticles is ascribed to a significantly increased absorption of $\mathrm{CO}_{2}$ during saturation. This process results in an increased $\mathrm{CO}_{2}$ concentration close to the PDMS-decorated, energetically favorable nanocavities at the nucleating surface. The utilization of surface cavities combined with optimized surface chemistry for efficient heterogeneous nucleation at the macromolecular length scale is of interest for the production of nanocellular foams with high cell densities and thus superior thermal insulation power.

\section{RESULTS AND DISCUSSION}

Core-Shell Raspberry-like Nanoparticle Synthesis and Characterization. Raspberry-like silica nanoparticles $\left(\mathrm{SiO}_{2}-\mathrm{R}\right)$ were synthesized by the reaction of Stöber silica nanoparticles with $\mathrm{NaBH}_{4}$, followed by the surface grafting of PDMS to yield rough silica core PDMS-shell hybrid nanoparticles $\left(\mathrm{SiO}_{2}-\mathrm{RP}\right)$. The reaction scheme is depicted in Figure 1a. (Hereinafter we abbreviate "nanoparticle" with NP.)
During the reaction of nearly smooth Stöber $\mathrm{SiO}_{2}\left(\mathrm{SiO}_{2}-\mathrm{S}\right)$ NPs with $\mathrm{NaBH}_{4}$, the high basicity of the dissolved $\mathrm{NaBH}_{4}$ results in the dissociation of $\mathrm{Si}-\mathrm{O}$ bonds and subsequently in the formation of soluble mono- and polysilicate species. Eventually the silicate species dissolved in the solution become supersaturated which leads to the formation of small $\mathrm{SiO}_{2}$ domains on the surface of the remaining silica NPs (Figure 1a, step 1). ${ }^{51,55,56}$

Scanning electron microscopy (SEM) images of $\mathrm{SiO}_{2}-\mathrm{S}$ and $\mathrm{SiO}_{2}-\mathrm{R}$ NPs with a diameter of approximately $155 \mathrm{~nm}$ are shown in Figure $1 \mathrm{~b}, \mathrm{c}$, respectively. The diameter of the $\mathrm{SiO}_{2}-\mathrm{R}$ NPs is defined as the diameter of a circle just large enough to enclose the $\mathrm{SiO}_{2}-\mathrm{R} \mathrm{NP}$ outer surface. Particles with diameters between 80 and $200 \mathrm{~nm}$ were prepared (see Materials and Methods section). Hereinafter, the numbers preceding " $\mathrm{SiO}_{2}$ " refer to the apparent particle diameter. For instance, $155 \mathrm{SiO}_{2}-\mathrm{S}$ refers to an NP with an average diameter of $155 \mathrm{~nm}$.

From Figure 1c, it is obvious that small silica domains (with diameters of $\sim 20-30 \mathrm{~nm}$ ) are present at the surface of the NPs after treatment with $\mathrm{NaBH}_{4}$, which is in agreement with the deposition of silicate species on the silica particle surface during the reaction. ${ }^{51}$ Following the successful synthesis of $\mathrm{SiO}_{2}-\mathrm{R}$ NPs with diameters of $\sim 80 \mathrm{~nm}, \sim 120 \mathrm{~nm}, \sim 155 \mathrm{~nm}$, and $\sim 200 \mathrm{~nm}$, a PDMS shell was grafted to the surface to yield the corresponding hybrid $\left(\mathrm{SiO}_{2}-\mathrm{RP}\right) \mathrm{NPs}$ (Figure 1a). In brief, $\mathrm{SiO}_{2}-\mathrm{R}$ was derivatized with (3-aminopropyl)-triethoxysilane (APTES), resulting in the formation of amine-functionalized NPs $\left(\mathrm{SiO}_{2}-\mathrm{R}_{-} \mathrm{NH}_{2}\right)$ (step 2). Subsequently, PDMS-grafted 

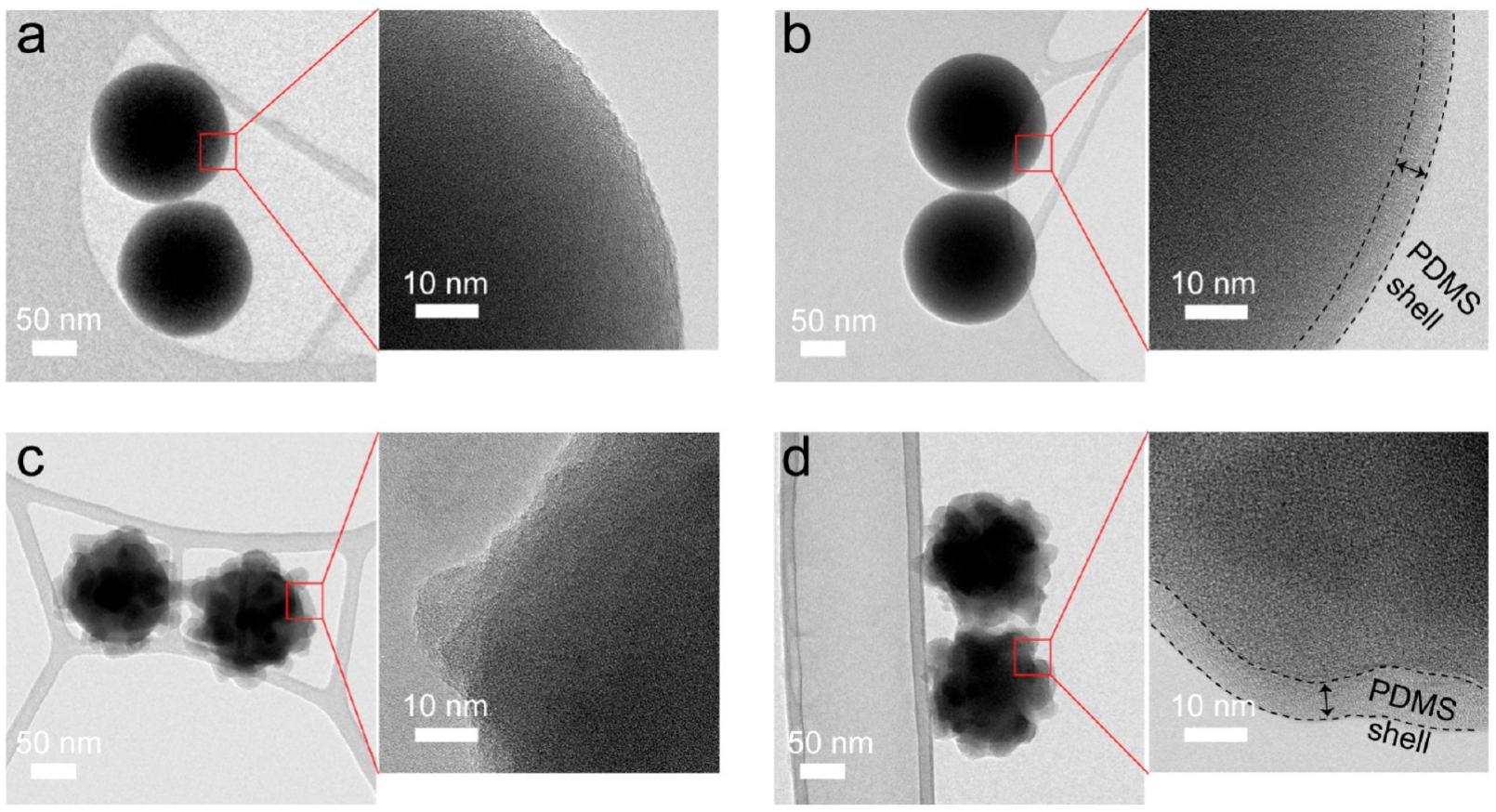

Figure 2. TEM images of (a) $155 \mathrm{SiO}_{2}-\mathrm{S}$, (b) $155 \mathrm{SiO}_{2}-\mathrm{SP}$, (c) $155 \mathrm{SiO}_{2}-\mathrm{R}$, and (d) $155 \mathrm{SiO}_{2}-\mathrm{RP} \mathrm{NPs}$.

core-shell NPs were prepared by the "grafting to" approach with monoglycidyl ether-terminated PDMS (step 3). We note here that prolonged sonication or even melt blending did not destroy the surface roughness of the (hybrid) raspberry-like NPs; that is, the NPs are stable enough for utilization as nucleating particles in nanocellular foaming.

Figure 1d shows Fourier transform infrared (FTIR) absorbance spectra of $\mathrm{SiO}_{2}, \mathrm{SiO}_{2}-\mathrm{R}, \mathrm{SiO}_{2}-\mathrm{R}_{-} \mathrm{NH}_{2}, \mathrm{SiO}_{2}-\mathrm{RP}$, and nearly smooth PDMS-grafted $\mathrm{NPs}\left(\mathrm{SiO}_{2}-\mathrm{SP}\right)$ with a (silica core) diameter of $\sim 155 \mathrm{~nm}$. The ethoxy groups remaining after the Stöber reaction with tetraethyl orthosilicate (TEOS) are clearly observed in the FTIR spectra of the $155 \mathrm{SiO}_{2}-\mathrm{S}$ particles; that is, the $\mathrm{CH}_{2} / \mathrm{CH}_{3}$ bending absorbance band at $1452 \mathrm{~cm}^{-1}$ and the $\mathrm{CH}_{2} / \mathrm{CH}_{3}$ absorbance band at 2980 $\mathrm{cm}^{-1} .57$ After $\mathrm{NaBH}_{4}$ etching to yield surface-roughened NPs, these absorbance bands disappear, which indicates quantitative hydrolysis of the remaining ethoxy groups of the $155 \mathrm{SiO}_{2}-\mathrm{R}$ NPs. ${ }^{51}$ The bands at $2980 \mathrm{~cm}^{-1}, 1450 \mathrm{~cm}^{-1}$, and $1380 \mathrm{~cm}^{-1}$ reappearing in the FTIR spectrum of $155 \mathrm{SiO}_{2}-\mathrm{R}_{-} \mathrm{NH}_{2}$ are assigned to the $\mathrm{CH}_{2}$ groups of the propyl spacer of surface tethered APTES. The presence of absorption bands ascribed to $\mathrm{CH}_{3}$ stretching at $2967 \mathrm{~cm}^{-1}$ and to $\mathrm{C}-\mathrm{H}$ bending at 1263 $\mathrm{cm}^{-1}$ in the FTIR spectrum of $155 \mathrm{SiO}_{2}-\mathrm{RP}$ NPs confirms the successful grafting of PDMS. ${ }^{58}$ The same absorption bands are observed in the FTIR spectrum of $\mathrm{SiO}_{2}$-SP NPs; their synthesis is described in the Materials and Methods section.

To determine the amount of PDMS grafted to the silica NPs, thermogravimetric analysis (TGA) was employed. Figure 1e shows the weight loss versus temperature curves for nonisothermal TGA measurements of nearly spherical and raspberry-like, amino-functionalized and PDMS-grafted NPs with silica (core) diameters of approximately $155 \mathrm{~nm}$. The results clearly show that the amount of PDMS covalently bound to the $\mathrm{SiO}_{2} \mathrm{NPs}$ with a rough surface is significantly higher, that is, $\sim 10.3 \mathrm{wt} \%$, than the amount covalently bound to the spherical NPs, that is, $\sim 3.0 \mathrm{wt} \%$. This nearly 3.4-fold increase in grafted PDMS weight is ascribed to the increased specific surface area of the raspberry-like NPs compared to the spherical NPs, as shown in Figure S1. For the NPs with a diameter of $155 \mathrm{~nm}$, the surface area increased from $32.4 \mathrm{~m}^{2}$ $\mathrm{g}^{-1}$ for the spherical NPs to $116.0 \mathrm{~m}^{2} \mathrm{~g}^{-1}$ for the raspberry-like NPs (see Figure S1). The nearly 3.6-fold increase in surface area is in good agreement with the 3.4-fold increase in amount of grafted PDMS. For the raspberry-like silica NPs with diameters of 200 and $120 \mathrm{~nm}$, the increase in PDMS grafting wt \% was in good agreement with the corresponding increase in surface area.

Based on the grafted PDMS mass obtained by TGA measurements, the molar mass of the grafted PDMS chains (i.e., $1000 \mathrm{~g} \mathrm{~mol}^{-1}$ ), and the Brunauer-Emmett-Teller (BET) surface area of the NPs, the PDMS grafting densities were calculated to be $\sim 0.6$ chains $\mathrm{nm}^{-2}$ for the $155 \mathrm{SiO}_{2}-\mathrm{SP}$ and $155-\mathrm{SiO}_{2}-\mathrm{RP}$ NPs. This number is lower than the earlier reported value of 0.9 for $\mathrm{SiO}_{2}$-SP NPs with diameters from 12 to $120 \mathrm{~nm}^{59}$ This difference is ascribed to the known overestimation of the surface area of Stöber silica NPs determined by BET measurements ${ }^{60-62}$ compared to the NP surface area calculated by simple arithmetic estimation based on the particle diameter. When using this simple arithmetic method for the determination of the grafting density of the $\mathrm{SiO}_{2}$-SP NPs with a particle diameter from 80 to $200 \mathrm{~nm}$, grafting density values close to 0.9 chains $\mathrm{nm}^{-2}$ were obtained. This result is in good agreement with values for $\mathrm{SiO}_{2}$-SP NPs reported in our previous work. ${ }^{59}$ Based on these results, we note that BET analysis is used here only to qualitatively show the significant differences in the surface area of the particles before and after roughening their surface.

Finally, transmission electron microscopy (TEM) was used to confirm the core-shell structure of the PDMS-grafted NPs. Figure $2 \mathrm{a}-\mathrm{d}$ shows TEM images of $155 \mathrm{~nm}$ bare and PDMSgrafted spherical and raspberry-like NPs. From these TEM images, it is clear that there is a thin PDMS shell around the $155 \mathrm{SiO}_{2}-\mathrm{SP}$ (Figure 2b) and $155 \mathrm{SiO}_{2}-\mathrm{RP}$ (Figure $2 \mathrm{~d}$ ) $\mathrm{NPs}$. The thickness of the PDMS shell on the NPs was estimated to 

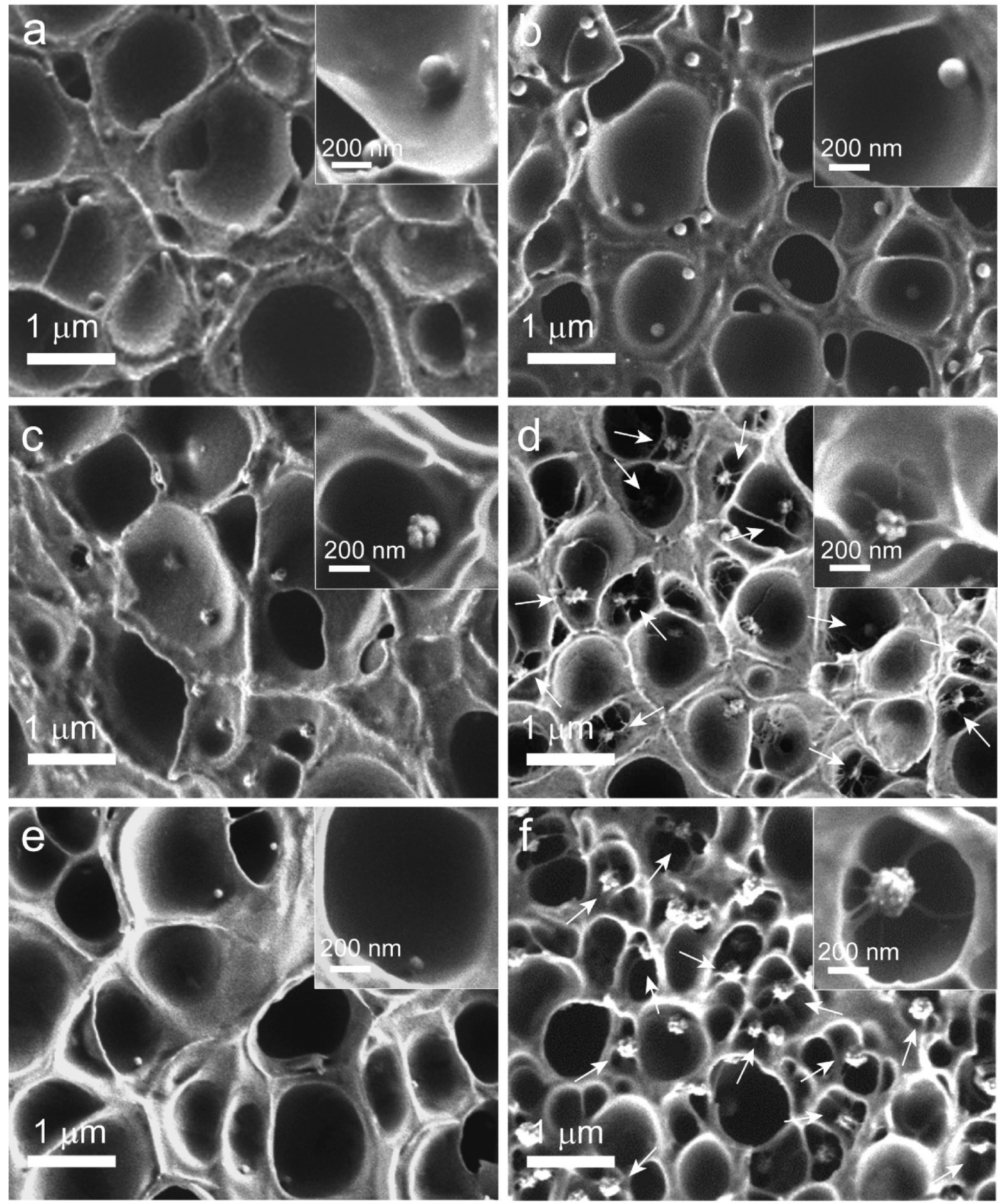

Figure 3. SEM images of cross-sectioned PMMA foams nucleated by (a) $155 \mathrm{SiO}_{2}-\mathrm{S}$, (b) $155 \mathrm{SiO}_{2} \mathrm{SP}_{\text {, (c) }} 155 \mathrm{SiO}_{2}-\mathrm{R},(\mathrm{d}) 155 \mathrm{SiO}{ }_{2}-\mathrm{RP},(\mathrm{e})$ $80 \mathrm{SiO}_{2}-\mathrm{RP}$, and (f) $200 \mathrm{SiO}_{2}-\mathrm{RP}$ NPs. The white arrows in (d) and (f) point toward the particles showing multiple cell nucleation events per particle. The insets show higher magnification images of nucleating NPs in cross-sectioned PMMA foam cells. The saturation pressure, foaming temperature, and foaming time were $55 \mathrm{bar}, 40^{\circ} \mathrm{C}$, and $1 \mathrm{~s}$, respectively.

be approximately $6.0 \pm 1.5 \mathrm{~nm}$, which agrees well with previous results reported for $\mathrm{SiO}_{2}$-SP NPs with silica-core diameters from 12 to $120 \mathrm{~nm}^{59}$

Following the successful synthesis and characterization of the NPs, we employed them as nucleating agents in $\mathrm{CO}_{2}$ assisted batch foaming of PMMA as presented and discussed in the next sections.

Nanocomposite Foaming and Multinucleation. Prior to foaming, the designer NPs were melt-blended in a PMMA matrix and pressed into films with a thickness of approximately $200 \mu \mathrm{m}$. For comparison of the nucleation efficiency, NPs with the same volume number density (i.e., $1.07 \times 10^{13}$ particles $\mathrm{cm}^{-3}$ ) were used for each nanocomposite film. Thus, assuming that the particles are well dispersed in the PMMA films and that each particle can nucleate the same number of foam cells, all nanocomposite films had the same volume number density of potential nucleation sites prior to foaming. The particles were well dispersed in PMMA prior to foaming, as observed from SEM images of cross-sectioned PMMA nanocomposite films (see Figure S3, Supporting Information).

The $\mathrm{CO}_{2}$ saturation pressure used for foaming was 55 bar, and following quick depressurization (i.e., within $2 \mathrm{~s}$ ), foams were prepared at a foaming temperature of $40{ }^{\circ} \mathrm{C}$ for $1 \mathrm{~s}$. This relatively short foaming time was chosen since we were primarily interested in the nucleation efficiency of the prepared particles and not in the well-developed foam morphology at 

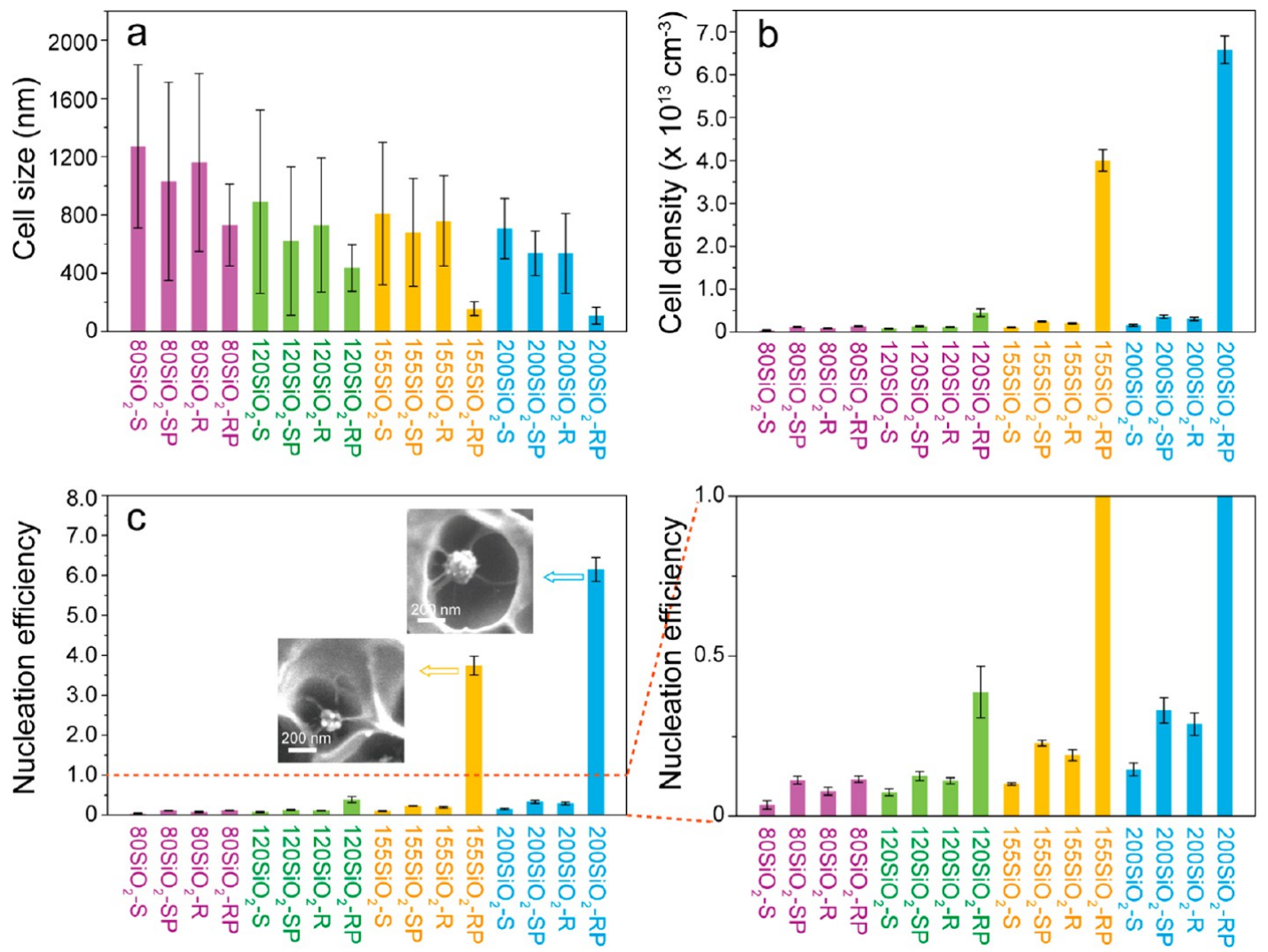

Figure 4. (a) Foam cell size, (b) cell density, and (c) cell nucleation efficiency for PMMA foams nucleated by $\mathrm{SiO}_{2}-\mathrm{S}, \mathrm{SiO}_{2}-\mathrm{SP}, \mathrm{SiO}_{2}-\mathrm{R}$, and $\mathrm{SiO}_{2}-\mathrm{RP}$ NPs with diameters of $\sim 80 \mathrm{~nm}, \sim 120 \mathrm{~nm}, \sim 155 \mathrm{~nm}$, and $\sim 200 \mathrm{~nm}$. The saturation pressure, foaming temperature, and foaming time were 55 bar, $40^{\circ} \mathrm{C}$, and $1 \mathrm{~s}$, respectively. The insets in (c) show SEM images of cross-sectioned PMMA foam cells showing the presence of multiple cells around single $155 \mathrm{SiO}_{2}-\mathrm{RP}$ and $200 \mathrm{SiO}_{2}-\mathrm{RP} \mathrm{NPs}$.

the end stages of foaming (i.e., after several tens of seconds to $\mathrm{min})$. Figure $3 \mathrm{a}-\mathrm{d}$ shows SEM images of cross-sectioned PMMA foams nucleated by $155 \mathrm{SiO}_{2}-\mathrm{S}, 155 \mathrm{SiO}_{2}-\mathrm{SP}, 155 \mathrm{SiO}_{2}-$ $\mathrm{R}$, and $155 \mathrm{SiO}_{2}-\mathrm{RP}$ NPs. It is clear that for the $1 \mathrm{~s}$ foaming time, the PMMA foams have thick cell walls and struts. Furthermore, the $155 \mathrm{SiO}_{2}-\mathrm{S}, 155 \mathrm{SiO}_{2}-\mathrm{SP}$, and $155 \mathrm{SiO}_{2}-\mathrm{R} \mathrm{NPs}$ are present at the polymer foam cell wall surface. The $155 \mathrm{SiO}_{2}-$ $S$ NPs are more embedded in the PMMA cell wall than the $155 \mathrm{SiO}_{2}$-SP NPs, which can be attributed to the low surface energy and high $\mathrm{CO}_{2}$-philicity of the decorated PDMS shell compared with the bare particles, resulting in the different interfacial interactions between the nanoparticles and the polymer gas mixture. ${ }^{63}$ This is in good agreement with the reported results for the nucleation behavior of pristine $\mathrm{SiO}_{2}$ and corresponding PDMS-grafted core-shell NPs with (core) diameters up to $120 \mathrm{~nm} .^{33,59}$

Interestingly, when examining the $155 \mathrm{SiO}_{2}-\mathrm{RP} \mathrm{NPs}$ embedded in the PMMA foams, we observed that most of these particles are surrounded by a few primary polymer foam cells (see Figure 3d). Of particular interest is that the cell walls in between these primary foam cells are much thinner than the non-nucleated/expanded PMMA matrix surrounding them and that the size of the cells around the $155 \mathrm{SiO}_{2}-\mathrm{RP}$ particles is fairly uniform. This observation points toward simultaneous multiple heterogeneous nucleation events per added particle. In addition, the thin wall between some foam cells appears to be ruptured or partly disappeared. This result indicates that cell coalescence occurs during the initial stages of nucleation. An explanation for this behavior is provided later.
The occurrence of multiple nucleation events per $155 \mathrm{SiO}_{2}-$ $\mathrm{RP}$ particles is promising for developing nanocellular foams with increased cell densities. To successfully exploit this possibility, it is of pivotal importance to obtain a deeper understanding of cell nucleation as a function of the surface roughening feature sizes. Therefore, we prepared $\mathrm{SiO}_{2}-\mathrm{R}$ and $\mathrm{SiO}_{2}$-RP NPs with diameters of $\sim 80 \mathrm{~nm}, \sim 120 \mathrm{~nm}$, and $\sim 200$ $\mathrm{nm}$ to explore this idea. Figure S2 shows SEM images of $80 \mathrm{SiO}_{2}-\mathrm{R}, 120 \mathrm{SiO}_{2}-\mathrm{R}$, and $200 \mathrm{SiO}_{2}-\mathrm{R} \mathrm{NPs}$. It is clear that the feature sizes of the roughened surfaces are different among the particles with different diameters, that is, $80 \mathrm{SiO}_{2}-\mathrm{R}$ has only a few small protrusions at its surface, while $200 \mathrm{SiO}_{2}-\mathrm{R}$ reveals numerous larger protruding features (Figure S2). It turned out that for the etching method used the initial Stöber silica NP size has an impact on the particle roughness. ${ }^{51}$

The SEM images of the cross-sectioned PMMA foams nucleated by $80 \mathrm{SiO}_{2}-\mathrm{RP}$ (Figure $3 \mathrm{e}$ ) and $200 \mathrm{SiO}_{2}-\mathrm{RP}$ (Figure 3f) reveal distinct differences in the foam morphology as well. For instance, the images of the foam nucleated by $200 \mathrm{SiO}_{2}-\mathrm{RP}$ NPs clearly show the presence of multiple cells around single nucleating particles; however, no multiple cell nucleation events are observed around single $80 \mathrm{SiO}_{2}-\mathrm{RP}$ NPs.

Below, we present how the nucleation efficiency of $\mathrm{SiO}_{2}-\mathrm{RP}$ NPs depends on the particle surface roughness for a PMMA foam prepared with a foaming time of $1 \mathrm{~s}$. Figure 4 shows the cell size (4a), cell density (4b), and nucleation efficiency (4c) values for foams nucleated by $\mathrm{SiO}_{2}-\mathrm{S}, \mathrm{SiO}_{2}-\mathrm{SP}, \mathrm{SiO}_{2}-\mathrm{R}$, and $\mathrm{SiO}_{2}-\mathrm{RP}$ NPs as a function of the silica particle diameter.

As can be clearly seen from Figure $4 \mathrm{a}$, the average cell size nucleated with $\mathrm{SiO}_{2}-\mathrm{RP}$ NPs is smaller than that nucleated 

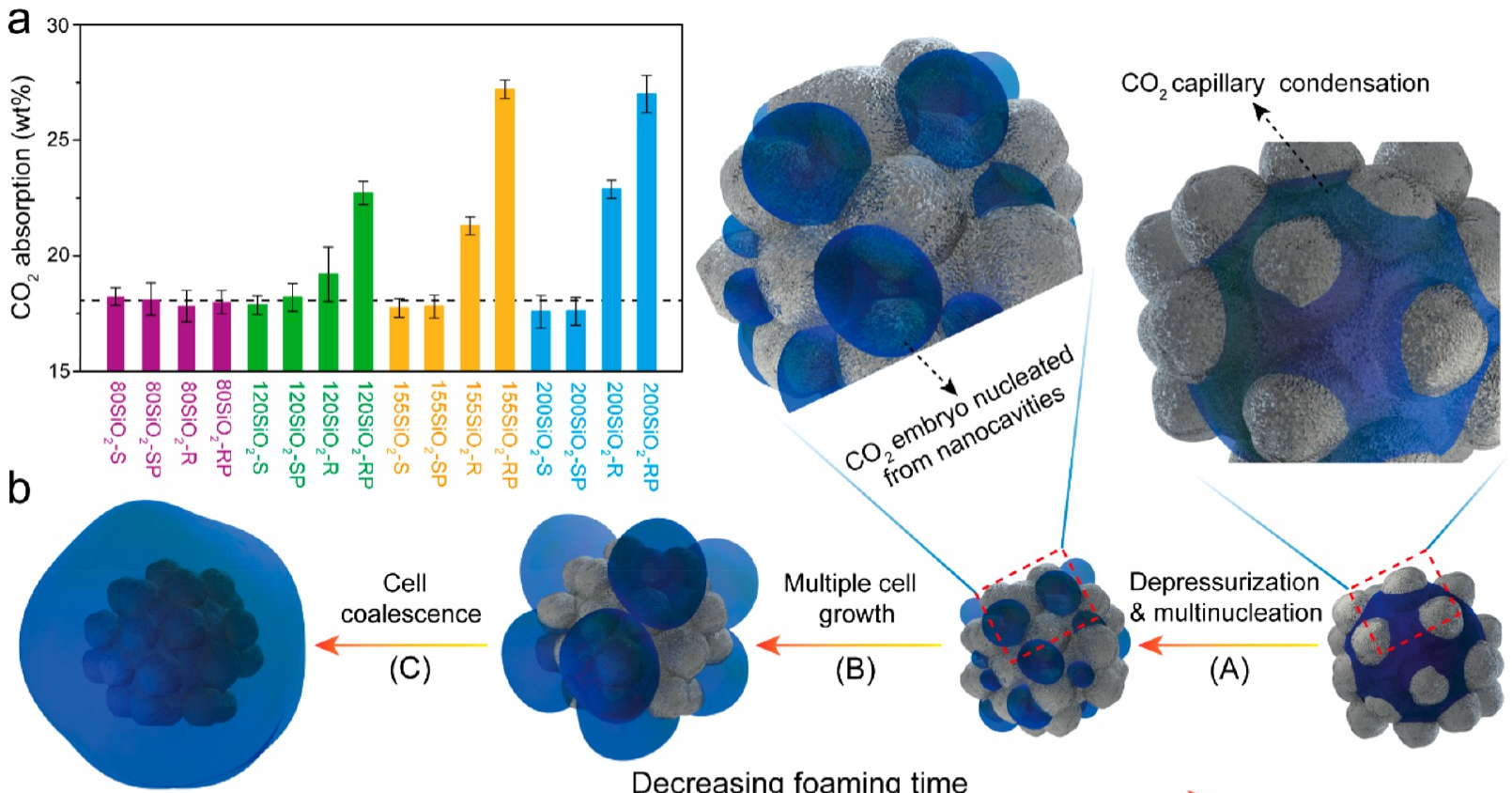

Decreasing foaming time
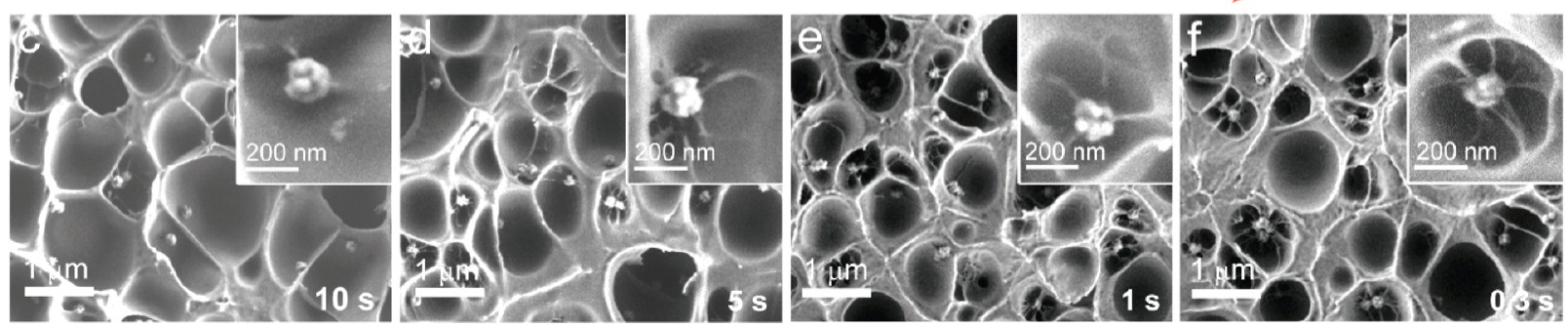

Figure 5. (a) $\mathrm{CO}_{2}$ absorption by $\mathrm{PMMA}$ films containing $\mathrm{SiO}_{2}-\mathrm{S}, \mathrm{SiO}_{2}-\mathrm{SP}, \mathrm{SiO}_{2}-\mathrm{R}$, and $\mathrm{SiO}_{2}-\mathrm{RP}$ particles with diameters between 80 and 200 $\mathrm{nm}$. The saturation pressure and time were $55 \mathrm{bar}$ and $4 \mathrm{~h}$, respectively. The dashed line shows the $\mathrm{CO}_{2}$ absorption by PMMA containing no NPs. (b) Schematic representation of the nucleation of multiple cells from PDMS-grafted raspberry-like silica NPs. SEM images of crosssectioned PMMA foams nucleated by $155 \mathrm{SiO}_{2}-\mathrm{RP} \mathrm{NPs}$ for (c) $10 \mathrm{~s}$, (d) $5 \mathrm{~s}$, (e) $1 \mathrm{~s}$, and (f) $0.3 \mathrm{~s}$. In the insets, the foam cell wall around a single nanoparticle is shown. The saturation pressure and foaming temperature were 55 bar and $40{ }^{\circ} \mathrm{C}$, respectively.

with $\mathrm{SiO}_{2}-\mathrm{S}, \mathrm{SiO}_{2}-\mathrm{SP}$ and $\mathrm{SiO}_{2}-\mathrm{R} \mathrm{NPs}$ with the same diameter. In addition, upon increasing the particle diameter from 80 to $200 \mathrm{~nm}$, the average cell size decreases, and the cell size distribution becomes narrower. SEM images of cross-sectioned PMMA foams nucleated by $80 \mathrm{SiO}_{2}-\mathrm{RP}$ particles did not reveal any multiple cell nucleation events per particle (see Figure $3 \mathrm{e}$ ), while for $120 \mathrm{SiO}_{2}-\mathrm{RP}$, this phenomenon was observed for some particles (Figure S4). The decrease in the number of multiple nucleation events is ascribed to the lower surface roughness of the $80-\mathrm{SiO}_{2}-\mathrm{RP}$ and $120 \mathrm{SiO}_{2}-\mathrm{RP} \mathrm{NPs}$, that is, resulting in a reduced number of effective nanocavities. However, for the PMMA foams nucleated by $155 \mathrm{SiO}_{2}-\mathrm{RP}$ and $200 \mathrm{SiO}_{2}-\mathrm{RP}$ particles, multiple cell nucleation events were observed, resulting in a higher $\mathrm{CO}_{2}$ consumption during cell growth than that during the growth of the foams without multiple cell nucleation events. This finding explains the reduction in cell size to $160 \pm 50 \mathrm{~nm}$ and $110 \pm 60 \mathrm{~nm}$ for the foams nucleated with $155 \mathrm{SiO}_{2}-\mathrm{RP}$ and $200 \mathrm{SiO}_{2}-\mathrm{RP}$ particles, respectively.

The occurrence of multiple cell nucleation events for $\mathrm{SiO}_{2}$ RP NPs with various roughnesses has, as expected, a significant effect on the cell density and nucleation efficiency values (Figure 4b,c). Compared to the other particle types, the $200 \mathrm{SiO}_{2}-\mathrm{RP} \mathrm{NPs}$ cause, similar to the $155 \mathrm{SiO}_{2}-\mathrm{RP} \mathrm{NPs}$, a significant increase in cell density and cell nucleation efficiency.
In fact, for the $200 \mathrm{SiO}_{2}-\mathrm{RP}$ NPs, the nucleation efficiency was $\sim 6.2$, which is the highest nucleation efficiency reported thus far.

In addition, $120 \mathrm{SiO}_{2}-\mathrm{RP}$ particles have a higher nucleation efficiency than $120 \mathrm{SiO}_{2}-\mathrm{S}, 120 \mathrm{SiO}_{2}-\mathrm{R}$, and $120 \mathrm{SiO}_{2}-\mathrm{SP} \mathrm{NPs}$, as well (see Figure $4 \mathrm{c}$ ). This result is again qualitatively explained by the presence of the nanocavities. However, $80 \mathrm{SiO}_{2}-\mathrm{RP} \mathrm{NPs}$ show a comparable nucleation efficiency with $80 \mathrm{SiO}_{2}$-SP NPs, which is ascribed to the presence of mainly convex surface domains at its particle surface. Compared to concave surface roughness, convex structures have a higher cell nucleation free energy. $^{47,48}$

From Figure 4, it is obvious that for the particle sizes evaluated, the $\mathrm{SiO}_{2}-\mathrm{R}$ NPs have nucleation efficiencies comparable to those of the $\mathrm{SiO}_{2}$-SP NPs, while the $\mathrm{SiO}_{2}-\mathrm{S}$ particles are the least effective nucleating agents. Overall, it is shown that NPs designed with a concave surface roughness are more efficient for use as nucleation agents than the nearly spherical NPs and that a combination of roughness with a $\mathrm{CO}_{2}$-philic low surface energy PDMS shell has a very large synergetic effect on PMMA foam cell nucleation.

Elucidation of the Multiple Foam Cell Nucleation Mechanism. The synergetic effect of a PDMS shell with the presence of cavities on the nucleation efficiency of $\mathrm{SiO}_{2}-\mathrm{RP}$ NPs was much higher than expected. In fact, we reasoned that 
for the higher number of cells to grow, more $\mathrm{CO}_{2}$ as a blowing agent must be available. Thus, the $\mathrm{CO}_{2}$ absorption of PMMA films containing $\mathrm{SiO}_{2}-\mathrm{S}, \mathrm{SiO}_{2}-\mathrm{SP}, \mathrm{SiO}_{2}-\mathrm{R}$, and $\mathrm{SiO}_{2}-\mathrm{RP}$ particles with diameters of $\sim 80 \mathrm{~nm}, \sim 120 \mathrm{~nm}, \sim 155 \mathrm{~nm}$, and $\sim 200 \mathrm{~nm}$ were determined to further elucidate the cell nucleation efficiency as a function of the particle type and size. The results are shown in Figure 5a. Clearly, PMMA films containing $\mathrm{SiO}_{2}-\mathrm{S}$ and $\mathrm{SiO}_{2}$-SP NPs have no significant differences in $\mathrm{CO}_{2}$ absorption from PMMA films without NPs regardless of the particle diameter. The same trend is observed for $80 \mathrm{SiO}_{2}-\mathrm{R}$ and $80 \mathrm{SiO}_{2}-\mathrm{RP}$ NPs. Hence, for these particles, the overall $\mathrm{CO}_{2}$ concentration is not altered, while locally in the PMMA films, the $\mathrm{CO}_{2}$ concentration may vary due to the presence of the PDMS shell. Upon increasing the surface roughness of the particles, for example, for the $120 \mathrm{SiO}_{2}-\mathrm{R}, 155 \mathrm{SiO}_{2}-\mathrm{R}$, and $200 \mathrm{SiO}_{2}-\mathrm{R} \mathrm{NPs}$, the amount of $\mathrm{CO}_{2}$ absorbed is expected to significantly increase. The presence of a PDMS shell increases the amount absorbed even more for these NPs. For instance, for the $200 \mathrm{SiO}_{2}-\mathrm{R}$ and $200 \mathrm{SiO}_{2}-\mathrm{RP}$ NPs, the increase in the amount of $\mathrm{CO}_{2}$ absorbed was $\sim 4.7 \mathrm{wt} \%$ and $\sim 8.8 \mathrm{wt} \%$, respectively, compared to the PMMA film containing no particles $(\sim 18.2$ wt $\%)$.

This increase in $\mathrm{CO}_{2}$ absorption for the rough particles is ascribed to capillary condensation of $\mathrm{CO}_{2}$ in the nanocavities. ${ }^{64-66}$ The even larger increase in $\mathrm{CO}_{2}$ absorption for the rough particles with a PDMS shell with diameters of $\sim 120$ $\mathrm{nm}, \sim 155 \mathrm{~nm}$, and $\sim 200 \mathrm{~nm}$ compared to their bare counterparts is attributed to the presence of $\mathrm{CO}_{2}$-philic molecules attached to the nanocavity surfaces, which is known to potentially enhance the absorption of $\mathrm{CO}_{2}{ }^{67-69}$

The higher physical blowing agent concentration close to the particle surface is favorable for increasing the nucleation rate, and combined with the presence of a low surface energy PDMS shell in the nanocavities, this property leads to a significant enhancement in the foam cell nucleation efficiency of these particles. Figure $5 \mathrm{~b}$ shows a schematic representation of the assumed mechanism leading to multiple cell nucleation events for raspberry-like PDMS-grafted silica NPs. Upon saturation of PMMA films containing $\mathrm{SiO}_{2}-\mathrm{RP} \mathrm{NPs}, \mathrm{CO}_{2}$ capillary condensation in the cavities results in the presence of significantly increased amounts of $\mathrm{CO}_{2}$ in close proximity to the nucleating particle surface. The nanocavities are energetically favorable nucleating sites and, together with the increased amount of available $\mathrm{CO}_{2}$, result in more than one nucleating event per particle (step A) and subsequent cell growth (step B) and cell coalescence (step C). This mechanism is further experimentally confirmed by the development of the foam cell morphology as a function of the foaming time for PMMA foams nucleated by $155 \mathrm{SiO}_{2}-\mathrm{RP} \mathrm{NPs}$, as shown in Figure $5 \mathrm{c}-\mathrm{f}$. Upon increasing the foaming time, the cell walls between these primary foam cells nucleated from the same single $155 \mathrm{SiO}_{2}-\mathrm{RP}$ appear to be ruptured or partly disappeared, leading to cell coalescence. In addition, the cell size and cell nucleation efficiency for PMMA foams, nucleated with $155 \mathrm{SiO}_{2}-\mathrm{S}$, $155 \mathrm{SiO}_{2}-\mathrm{SP}, 155 \mathrm{SiO}_{2}-\mathrm{R}$, and $155 \mathrm{SiO}_{2}-\mathrm{RP} \mathrm{NPs}$, were also determined as a function of the foaming time (see Figure S5).

Overall, we experimentally demonstrated that multiple cell nucleation events on a single NP can be obtained through the use of PDMS-decorated core-shell raspberry-like NPs as nucleation agents. These designer NPs exhibit significantly higher cell nucleation efficiency in PMMA nanocellular foaming than their bare and nearly spherical counterparts. We also utilized $155 \mathrm{SiO}_{2}$-RP NPs in the $\mathrm{CO}_{2}$-assisted batch foaming of polystyrene, and the corresponding SEM images also revealed the occurrence of multiple cell nucleation events (see Figure S6). Hence, these hybrid core-shell NPs are very promising as highly efficient cell nucleation agents in polymer nanocellular foaming in general.

To fully exploit the high nucleation efficiency of $\mathrm{SiO}_{2}-\mathrm{RP}$ particles, it is of pivotal importance to find foaming strategies and foam matrixes that both allow the introduction of a high number of cell nuclei and ensure early cell stabilization during the foaming process to prevent cell coalescence. For instance, without optimization of any of the foaming parameters or the composition of the PMMA nanocomposite matrix, we obtained a high cell density of $\sim 6.6 \times 10^{13}$ cells $\mathrm{cm}^{-3}$, which is already very close to the order of magnitude of interest (i.e., $10^{14}$ cells $\mathrm{cm}^{-3}$ ). Future work must be directed toward developing new strategies for sufficiently increasing the surface roughness of NPs with a particle diameter $<100 \mathrm{~nm}$. This objective is essential since at the same weight percentage of particle loading, a higher number of effective nucleation agents is available when smaller particles are used.

\section{CONCLUSION}

In summary, bare and PDMS-decorated nearly spherical and raspberry-like silica NPs were synthesized and utilized as efficient nucleation agents in $\mathrm{CO}_{2}$-blown PMMA nanocellular foams. Raspberry-like nanoparticles with a thin PDMS shell exhibit a higher nucleation efficiency than their nearly spherical counterparts. Multiple nucleating events per particle were observed for $\mathrm{SiO}_{2}-\mathrm{RP}$ NPs with core diameters of 155 and 200 $\mathrm{nm}$. The highest nucleation efficiency obtained was 6.2 for $200 \mathrm{SiO}_{2}-\mathrm{RP}$ NPs. The significantly higher nucleation efficiency (well above unity) of the core-shell raspberry-like nanoparticles is attributed to the synergistic effect between the thin PDMS shell and the presence of cavities on the nanoparticles surface as well as the higher $\mathrm{CO}_{2}$ absorption. This results in an increased physical blowing agent concentration available for nucleation close to the energetically favorable nanocavities serving as nucleating sites. Hence, PDMS-decorated core-shell raspberry-like nanoparticles are very promising for use as an interesting class of highly efficient nucleation agents. To improve our understanding of multiple cell nucleation events, future work should be directed toward the quantification of the relationship between nucleation energy barrier and surface cavity structure dimensions as well optimization of foaming conditions to stabilize the multiple nucleated cells during the early stages of foaming.

\section{MATERIALS AND METHODS}

Materials. PMMA was purchased from Arkema (VM100, i.e., a PMMA-co-EA polymer, $\rho=1.18 \mathrm{~g} \mathrm{~cm}^{-3}$ ) (La Garenne-Colombes, France). Absolute ethanol for analysis was purchased from Merck (Darmstad, Germany). Absolute tetrahydrofuran (THF), 2-propanol (99.8\%), and chloroform (99.9\%) were purchased from Biosolve (Valkenswaard, The Netherlands). Monoglycidyl ether-terminated poly(dimethylsilane) (PDMS-G) $\left(M_{\mathrm{w}}=1000 \mathrm{~g} \mathrm{~mol}^{-1}\right)$, ammonium hydroxide solution (28-30\%), (3-aminopropyl)triethoxysilane (APTES, $\geq 98 \%$ ), sodium borohydride purum $\left(\mathrm{NaBH}_{4}\right.$, p.a., $\geq 96 \%$, gas-volumetric), polyvinylpyrrolidone with a molar mass of 40,000 $\mathrm{g}$ $\mathrm{mol}^{-1}$ (PVP40), and tetraethyl orthosilicate (TEOS, $\geq 99.0 \%$ ) were purchased from Sigma-Aldrich (St. Louis, MO, USA). Milli-Q water was produced by a Millipore Synergy system (Billerica, MA, USA). Unless otherwise mentioned, all other chemicals were used as received. 
Stöber Silica Nanoparticle $\left(\mathrm{SiO}_{2}\right)$ Synthesis. $\mathrm{SiO}_{2}$ particles with diameters of $\sim 80 \mathrm{~nm}, \sim 120 \mathrm{~nm}, \sim 155 \mathrm{~nm}, \sim 180 \mathrm{~nm}, \sim 200 \mathrm{~nm}$, and $\sim 310 \mathrm{~nm}$ were prepared by the Stöber method. To prepare NPs with a diameter of $\sim 155 \mathrm{~nm}, 100 \mathrm{~mL}$ of ethanol was mixed with $8 \mathrm{~mL}$ of Milli-Q water and $10 \mathrm{~mL}$ of TEOS in the presence of $5 \mathrm{~mL}$ of ammonium hydroxide while stirring at $500 \mathrm{rpm}$ at $50^{\circ} \mathrm{C}$. After $4.5 \mathrm{~h}$, the $\mathrm{SiO}_{2}$ dispersion obtained was centrifuged at $10,000 \mathrm{rpm}$ for 30 min. Subsequently, the collected $\mathrm{SiO}_{2}$ was redispersed in ethanol and centrifuged again. This washing step was repeated 2 more times, followed by vacuum-drying the collected $\mathrm{SiO}_{2}$ nanoparticles at room temperature for $12 \mathrm{~h}$. To prepare NPs with a diameter of $\sim 80 \mathrm{~nm}$, $168 \mathrm{~mL}$ of ethanol was mixed with $28 \mathrm{~mL}$ of Milli-Q water and $30 \mathrm{~mL}$ of TEOS in the presence of $2 \mathrm{~mL}$ of ammonium hydroxide while stirring for $1.5 \mathrm{~h}$ at $500 \mathrm{rpm}$ at room temperature. To synthesize the $\sim 120 \mathrm{~nm}$ particles, $100 \mathrm{~mL}$ of ethanol was mixed with $8 \mathrm{~mL}$ of Milli$\mathrm{Q}$ water and $5 \mathrm{~mL}$ of TEOS in a round-bottom flask stirring at 500 $\mathrm{rpm}$, and subsequently $5 \mathrm{~mL}$ of ammonium hydroxide was added and reacted for $3 \mathrm{~h}$ at $50{ }^{\circ} \mathrm{C}$. To synthesize the $\sim 180 \mathrm{~nm}$ particles, 100 $\mathrm{mL}$ of ethanol was mixed with $8 \mathrm{~mL}$ of Milli-Q water and $10 \mathrm{~mL}$ of TEOS in the presence of $5.3 \mathrm{~mL}$ of ammonium hydroxide in a 250 $\mathrm{mL}$ round-bottom flask while stirring at $500 \mathrm{rpm}$. The reaction was conducted for $4.5 \mathrm{~h}$ at $50{ }^{\circ} \mathrm{C}$. To synthesize the $\sim 200 \mathrm{~nm}$ particles, $100 \mathrm{~mL}$ of ethanol was mixed with $8 \mathrm{~mL}$ of Milli-Q water and $10 \mathrm{~mL}$ of TEOS in the presence of $5.6 \mathrm{~mL}$ of ammonium hydroxide in a 250 $\mathrm{mL}$ round-bottom flask while stirring at $500 \mathrm{rpm}$. The reaction was conducted for $4.5 \mathrm{~h}$ at $50{ }^{\circ} \mathrm{C}$. To synthesize the $\sim 310 \mathrm{~nm}$ particles, $100 \mathrm{~mL}$ of ethanol was mixed with $8 \mathrm{~mL}$ of Milli- $\mathrm{Q}$ water and $10 \mathrm{~mL}$ of TEOS in a round-bottom flask stirring at $500 \mathrm{rpm}$, and subsequently, $7.0 \mathrm{~mL}$ of ammonium hydroxide was added and reacted for $4.5 \mathrm{~h}$ at $50{ }^{\circ} \mathrm{C}$. The collection, washing, and drying steps of these nanoparticles were the same as those described for the $\sim 155$ nm nanoparticles.

Nanoparticles Hydrolysis. To introduce silanol groups on the surface of the prepared $\mathrm{SiO}_{2}$ nanoparticles, the particles were redispersed in Milli-Q water by sonication (BRANSON 2510, Canada) for $1 \mathrm{~h}$. Subsequently, hydrochloric acid was added to the dispersion while stirring at $500 \mathrm{rpm}$ until the $\mathrm{pH}$ of the solution reached a value of approximately 1 . After $4 \mathrm{~h}$, the dispersion was centrifuged at $10,000 \mathrm{rpm}$ for $30 \mathrm{~min}$. The collected nanoparticles were redispersed in Milli- $Q$ water and centrifuged again. This washing step was repeated 2 more times, followed by drying the silanolfunctionalized nanoparticles $\left(\mathrm{SiO}_{2}-\mathrm{OH}\right)$ under vacuum at room temperature for $12 \mathrm{~h}$.

APTES Modification of Silica Nanoparticles. First, $1.5 \mathrm{~g}$ of $\mathrm{SiO}_{2}-\mathrm{OH}$ nanoparticles were redispersed in $50 \mathrm{~mL}$ of ethanol, followed by the addition of $7.5 \mathrm{~mL}$ of APTES. The dispersion was left stirring at $500 \mathrm{rpm}$ at room temperature for $17 \mathrm{~h}$. The APTESfunctionalized nanoparticles $\left(\mathrm{SiO}_{2}-\mathrm{NH}_{2}\right)$ were collected by centrifugation at $10,000 \mathrm{rpm}$ for $30 \mathrm{~min}$, redispersed in ethanol, and centrifuged again. This washing step was repeated 2 more times, followed by drying the collected $\mathrm{SiO}_{2}-\mathrm{NH}_{2}$ nanoparticles under vacuum at room temperature for $12 \mathrm{~h}$.

PDMS-G Grafting to Silica Nanoparticles. First, $1.0 \mathrm{~g}$ of $\mathrm{SiO}_{2}-$ $\mathrm{NH}_{2}$ NPs was redispersed in $20.5 \mathrm{~mL}$ of THF and $15 \mathrm{~g}$ of PDMS-G while stirring at $500 \mathrm{rpm}$ for $1 \mathrm{~h}$, followed by sonication for $1 \mathrm{~h}$. Subsequently, THF was removed by rotary evaporation, and the resulting silica nanoparticle dispersion in PDMS-G was immersed in an oil bath thermostated at $80{ }^{\circ} \mathrm{C}$ for $17 \mathrm{~h}$. After cooling to room temperature, the reaction mixture was washed with THF and centrifuged at $10,000 \mathrm{rpm}$ for $30 \mathrm{~min}$. This washing step was repeated 2 more times, followed by vacuum-drying the PDMS-Ggrafted silica nanoparticles $\left(\mathrm{SiO}_{2}-\mathrm{SP}\right)$ at room temperature for $12 \mathrm{~h}$.

Synthesis and Modification of Raspberry-like Nanoparticles. To synthesize NPs with enhanced surface roughness of $\sim 80$ $\mathrm{nm}, 0.3 \mathrm{~g}$ of Stöber silica NPs of $\sim 80 \mathrm{~nm}$ and $0.25 \mathrm{~g}$ of PVP were redispersed in $10 \mathrm{~mL}$ of Milli- $\mathrm{Q}$ water by sonication for $30 \mathrm{~min}$. Subsequently, $0.6 \mathrm{~g}$ of $\mathrm{NaBH}_{4}$ was added to the dispersion while stirring at $500 \mathrm{rpm}$ at room temperature for another $30 \mathrm{~min}$. The resulting mixture was reacted at $50{ }^{\circ} \mathrm{C}$ for $1 \mathrm{~h}$ and $15 \mathrm{~min}$. Stöber silica nanoparticles with diameters of $\sim 155 \mathrm{~nm}, \sim 180 \mathrm{~nm}$, and $\sim 310$ $\mathrm{nm}$ were used to synthesize surface-roughened nanoparticles of $\sim 120$ $\mathrm{nm}, \sim 155 \mathrm{~nm}$, and $\sim 200 \mathrm{~nm}$, respectively, and the reactions were conducted for $3 \mathrm{~h}$ and $20 \mathrm{~min}, 3.5 \mathrm{~h}$, and $6 \mathrm{~h}$, respectively. The other steps for the synthesis of these surface-roughened NPs (with diameters from 120 to $200 \mathrm{~nm}$ ) were the same as described for the synthesis of rough surface NPs of $\sim 80 \mathrm{~nm}$. Subsequently, the obtained NPs featuring rough surfaces were collected by centrifugation at $10,000 \mathrm{rpm}$ for $30 \mathrm{~min}$, redispersed in Milli- $\mathrm{Q}$ water, and centrifuged again. This washing step was repeated 2 more times, followed by drying the collected nanoparticles under vacuum at room temperature for $12 \mathrm{~h}$. The processes of amino functionalization of and PDMS-G grafting to the surface-roughened nanoparticles were the same as those described for the Stöber silica nanoparticles.

Nanocomposite Preparation. Nanocomposites were prepared by dispersing the same amount of (functionalized) silica nanoparticles $\left(1.07 \times 10^{13} \mathrm{~cm}^{-3}\right)$ in PMMA with a mini-extruder (DSM Xplore, The Netherlands). In a typical procedure, a dry blend of nanoparticles and PMMA was fed to the extruder followed by internal mixing for 3 $\min$. The barrel temperature was set to $155^{\circ} \mathrm{C}$, and the screw speed was $100 \mathrm{rpm}$. Subsequently, the PMMA nanocomposite was collected and left to cool to room temperature.

Film Preparation. A hot press (Fontijne, The Netherlands) was used to press $\sim 0.2 \mathrm{~mm}$-thick nanocomposite films in a mold $(4 \times 3$ $\mathrm{cm})$. The press temperature, applied load, and press time were 180 ${ }^{\circ} \mathrm{C}, 250 \mathrm{kN}$, and $10 \mathrm{~min}$, respectively.

Batch Foaming of Nanocomposite Films. The nanocomposite PMMA films were saturated with $\mathrm{CO}_{2}(55 \mathrm{bar})$ in an autoclave for $4 \mathrm{~h}$ at room temperature followed by rapid depressurization. Subsequently, the PMMA nanocomposite films were immersed in a water bath thermostated at $40{ }^{\circ} \mathrm{C}$ for different foaming times $(0.3 \mathrm{~s}, 1 \mathrm{~s}, 5 \mathrm{~s}$, $10 \mathrm{~s}$, or $30 \mathrm{~s}$ ), after which the samples were quenched in an ice bath for $30 \mathrm{~min}$. The samples were left to dry in air for at least $12 \mathrm{~h}$ prior to further analysis.

Fourier Transform Infrared Spectroscopy. FTIR spectra were collected with a Bruker ALPHA single attenuated total reflection (ATR) FTIR spectrometer equipped with a single reflection ATR crystal (Bruker Optic GmbH, Ettlingen, Germany). The spectra were collected in the range of $400-4000 \mathrm{~cm}^{-1}$ (spectral resolution of 4 $\mathrm{cm}^{-1}, 128 \mathrm{scans}$ ). Background spectra were recorded against air.

Thermogravimetric Analysis. The weight loss of the (modified) particles as a function of temperature was measured with a TGA400 (PerkinElmer, Inc., Waltham, MA, USA). A sample weighing 3-6 $\mathrm{mg}$ was loaded into a platinum pan, and the temperature was set to 50 ${ }^{\circ} \mathrm{C}$ to stabilize. Subsequently, the sample was heated to $900{ }^{\circ} \mathrm{C}$ at a heating rate of $20^{\circ} \mathrm{C} \mathrm{min}{ }^{-1}$. The applied air flow was $20 \mathrm{~mL} \mathrm{~min}{ }^{-1}$.

Transmission Electron Microscopy. TEM was performed with an FEI/Philips CM300 system (Eindhoven, The Netherlands). Diluted particle dispersions in THF were deposited on the carbon side of a carbon/copper grid (HC200-Cu) (EMS, Germany) prior to imaging. Images were obtained in the bright-field mode with a $300 \mathrm{kV}$ acceleration voltage.

Scanning Electron Microscopy. For SEM, a high-resolution scanning electron microscope (JEOL Field Emission JSM-633OF, JEOL Benelux, Nieuw-Vennep, The Netherlands) was employed at an acceleration voltage of $5 \mathrm{keV}$. Prior to analysis, the nanocomposite foams were freeze fractured following cooling in liquid nitrogen for 5 $\min$.

Surface Area Measurement for Nanoparticles. The specific surface area of the nanoparticles was measured from the nitrogen adsorption isotherm obtained at $300{ }^{\circ} \mathrm{C}$ using an ASAP 2010 sorptometer (Micromeritics). Approximately $100 \mathrm{mg}$ of nanoparticle powder was used for each measurement.

$\mathrm{CO}_{2}$ Absorption Measurement. To measure the absorption of $\mathrm{CO}_{2}$, PMMA nanocomposite films containing the same amount of the respective nanoparticles were saturated in $\mathrm{CO}_{2}$ at 55 bar for $4 \mathrm{~h}$. The weights of the PMMA (nanocomposite) films before and after $\mathrm{CO}_{2}$ saturation were measured.

Calculation of PDMS Grafting Density. The grafting density (D) of the PDMS-decorated NP surface was determined according to eq 1: 


$$
D=\frac{K \times(m / M)}{S}
$$

where $K=6.02 \times 10^{23} \mathrm{~mol}^{-1}$, which is Avogadro's number, and $m$ is the weight of PDMS grafted per gram of NPs (determined from TGA), $M=1000 \mathrm{~g} \cdot \mathrm{mol}^{-1}$, which is the molar mass of the PDMS used, and $S$ is the surface area per gram of NPs, which was determined by BET.

Calculation of Cell Density and Nucleation Efficiency. The cell size and cell density were obtained by analyzing the obtained cross-sectional SEM images. The cell density $N_{v}$ of the foams was calculated according to Kumar's theoretical approximation. ${ }^{70}$ No direct measurements of cell dimensions over the micrograph are required in this method; only the micrograph area $(A)$ and the total number of cells $(n)$ contained therein are measured. Together with the magnification factor of the micrograph $(M)$, the values enabling $N_{v}$ to be calculated according to eq 2 :

$$
N_{v}=\left[\frac{\left(n M^{2}\right)}{A}\right]^{3 / 2}
$$

By combining $N_{v}$ with the volume expansion ratio $(B)$ of nanocomposite films after foaming, the cell numbers per $\mathrm{cm}^{3}$ of unfoamed materials $(N)$ can be calculated according to eq 3 :

$$
N=N_{v} \times B
$$

The cell densities mentioned in the main text are all refer to $N$. In addition, the nucleation efficiency $(f)$ of nanoparticles during foaming can be calculated as

$$
f=N / C
$$

where $C$ is the number of nanoparticles per $\mathrm{cm}^{3}$ (i.e., $1.07 \times 10^{13}$ ) used for foaming.

Figure S7 shows how we calculated the number of cells in the occasion of multiple cell nucleating events occurring around a particle.

\section{ASSOCIATED CONTENT}

\section{(s) Supporting Information}

The Supporting Information is available free of charge at https://pubs.acs.org/doi/10.1021/acsnano.9b06837.

BET results, SEM images for $\mathrm{SiO}_{2}-\mathrm{R}$ nanoparticles with different diameters, nanoparticles dispersion in PMMA, and cross-sectioned PMMA foams nucleated by $120 \mathrm{SiO}_{2}-\mathrm{RP}$. Cell size and nucleation efficiency as a function of foaming time, and SEM images of crosssectioned polystyrene foams nucleated by $150 \mathrm{SiO}_{2}-\mathrm{RP}$. SEM images show the number of cells in the occasion of multiple cell nucleating events occurring around a particle (PDF)

\section{AUTHOR INFORMATION}

\section{Corresponding Authors}

Joost Duvigneau - Materials Science and Technology of Polymers, MESA+ Institute for Nanotechnology, University of Twente 7500 AE Enschede, The Netherlands; (1) orcid.org/0000-0002-

2810-2768; Email: j.duvigneau@utwente.nl

G. Julius Vancso - Materials Science and Technology of Polymers, MESA+ Institute for Nanotechnology, University of Twente 7500 AE Enschede, The Netherlands; ㅇo이.org/0000-0003-

4718-0507; Email: g.j.vancso@utwente.nl

\section{Authors}

Shanqiu Liu - Materials Science and Technology of Polymers, MESA+ Institute for Nanotechnology, University of Twente 7500 AE Enschede, The Netherlands
Sida Yin - Materials Science and Technology of Polymers, MESA + Institute for Nanotechnology, University of Twente 7500 AE Enschede, The Netherlands

Complete contact information is available at:

https://pubs.acs.org/10.1021/acsnano.9b06837

\section{Notes}

The authors declare no competing financial interest.

\section{ACKNOWLEDGMENTS}

The authors would like to thank the MESA+ Institute for Nanotechnology of the University of Twente for financial support. S.L. acknowledges the China Scholarship Council for funding.

\section{REFERENCES}

(1) Notario, B.; Pinto, J.; Rodriguez-Perez, M. Nanoporous Polymeric Materials: ANew Class of Materials with Enhanced Properties. Prog. Mater. Sci. 2016, 78, 93-139.

(2) Forest, C.; Chaumont, P.; Cassagnau, P.; Swoboda, B.; Sonntag, P. Polymer Nano-Foams for Insulating Applications Prepared from $\mathrm{CO}_{2}$ Foaming. Prog. Polym. Sci. 2015, 41, 122-145.

(3) Liu, S.; Duvigneau, J.; Vancso, G. J. Nanocellular Polymer Foams as Promising High Performance Thermal Insulation Materials. Eur. Polym. J. 2015, 65, 33-45.

(4) Costeux, S. $\mathrm{CO}_{2}$-Blown Nanocellular Foams. J. Appl. Polym. Sci. 2014, 131, 41293.

(5) Chen, L.; Rende, D.; Schadler, L. S.; Ozisik, R. Polymer Nanocomposite Foams. J. Mater. Chem. A 2013, 1, 3837-3850.

(6) Eaves, D. Handbook of Polymer Foams; Rapra Technology Ltd.: Shrewsbury, 2004; pp 1-6.

(7) Notario, B.; Pinto, J.; Solorzano, E.; De Saja, J. A.; Dumon, M.; Rodríguez-Pérez, M. A. Experimental Validation of the Knudsen Effect in Nanocellular Polymeric Foams. Polymer 2015, 56, 57-67.

(8) Pinto, J.; Notario, B.; Verdejo, R.; Dumon, M.; Costeux, S.; Rodriguez-Perez, M. A. Molecular Confinement of Solid and Gaseous Phases of Self-Standing Bulk Nanoporous Polymers Inducing Enhanced and Unexpected Physical Properties. Polymer 2017, 113, 27-33.

(9) Lee, S.-T. Polymeric Foams: Technology and Developments in Regulation, Process, and Products; CRC Press: Boca Raton, 2009; pp $20-25$.

(10) Notario, B.; Pinto, J.; Rodríguez-Pérez, M. Towards a New Generation of Polymeric Foams: PMMA Nanocellular Foams with Enhanced Physical Properties. Polymer 2015, 63, 116-126.

(11) Li, L.; Shen, X.; Hong, S. W.; Hayward, R. C.; Russell, T. P. Fabrication of Co-Continuous Nanostructured and Porous Polymer Membranes: Spinodal Decomposition of Homopolymer and Random Copolymer Blends. Angew. Chem., Int. Ed. 2012, 51, 4089-4094.

(12) Zhang, X.; Chang, D.; Liu, J.; Luo, Y. Conducting Polymer Aerogels from Supercritical $\mathrm{CO}_{2}$ Drying PEDOT-PSS Hydrogels. $J$. Mater. Chem. 2010, 20, 5080-5085.

(13) Hedrick, J. L.; Miller, R. D.; Hawker, C. J.; Carter, K. R.; Volksen, W.; Yoon, D. Y.; Trollsås, M. Templating Nanoporosity in Thin-Film Dielectric Insulators. Adv. Mater. 1998, 10, 1049-1053.

(14) Park, S. H.; Xia, Y. Macroporous Membranes with Highly Ordered and Three-Dimensionally Interconnected Spherical Pores. Adv. Mater. 1998, 10, 1045-1048.

(15) Du Fresne Von Hohenesche, C.; Schmidt, D.; Schadler, V. Nanoporous Melamine-Formaldehyde Gels by Microemulsion Templating. Chem. Mater. 2008, 20, 6124-6129.

(16) Bledzki, A. K.; Faruk, O. Effects of the Chemical Foaming Agents, Injection Parameters, and Melt-Flow Index on the Microstructure and Mechanical Properties of Microcellular InjectionMolded Wood-Fiber/Polypropylene Composites. J. Appl. Polym. Sci. 2005, 97, 1090-1096. 
(17) Klempner, D. Handbook of Polymeric Foams and Foam Technology; Hanser: Munich, 1991; pp 6-13.

(18) Zeng, C.; Han, X.; Lee, L. J.; Koelling, K. W.; Tomasko, D. L. Polymer-Clay Nanocomposite Foams Prepared Using Carbon Dioxide. Adv. Mater. 2003, 15, 1743-1747.

(19) Park, C. B.; Behravesh, A. H.; Venter, R. D. Low Density Microcellular Foam Processing in Extrusion Using $\mathrm{CO}_{2}$. Polym. Eng. Sci. 1998, 38, 1812-1823.

(20) Tomasko, D. L.; Li, H.; Liu, D.; Han, X.; Wingert, M. J.; Lee, L. J.; Koelling, K. W. A Review of $\mathrm{CO}_{2}$ Applications in the Processing of Polymers. Ind. Eng. Chem. Res. 2003, 42, 6431-6456.

(21) Jacobs, L. J.; Kemmere, M. F.; Keurentjes, J. T. Sustainable Polymer Foaming Using High Pressure Carbon Dioxide: A Review on Fundamentals, Processes and Applications. Green Chem. 2008, 10, 731-738.

(22) Aram, E.; Mehdipour-Ataei, S. A Review on the Micro-and Nanoporous Polymeric Foams: Preparation and Properties. Int. J. Polym. Mater. 2016, 65, 358-375.

(23) Costeux, S.; Lantz, D. R.; Beaudoin, D. A.; Barger, M. A. Continuous Process for Extruding Nanoporous Foam. U.S. Patent 9145478B2, 2015.

(24) Sandler, J. K. W.; Francis, T.; Lopes, P. M. S. Nanoporous Polymer Foams. U.S. Patent 8529808B2, 2013.

(25) Costeux, S.; Zhu, L. Low Density Thermoplastic Nanofoams Nucleated by Nanoparticles. Polymer 2013, 54, 2785-2795.

(26) Costeux, S.; Bunker, S. P.; Jeon, H. K. Homogeneous Nanocellular Foams from Styrenic-Acrylic Polymer Blends. J. Mater. Res. 2013, 28, 2351-2365.

(27) Liao, Z.-E.; Yeh, S.-K.; Chu, C.-C.; Tseng, T.-W. Critical Parameters of Generating PMMA Nanocellular Foam. Annu. Technol. Conf-Soc. Plast. Eng. 2016, 1773-1778.

(28) Tammaro, D.; Astarita, A.; Di Maio, E.; Iannace, S. Polystyrene Foaming at High Pressure Drop Rates. Ind. Eng. Chem. Res. 2016, 55, 5696-5701.

(29) Pinto, J.; Dumon, M.; Pedros, M.; Reglero, J.; Rodriguez-Perez, M. A. Nanocellular $\mathrm{CO}_{2}$ Foaming of PMMA Assisted by Block Copolymer Nanostructuration. Chem. Eng. J. 2014, 243, 428-435.

(30) Li, L.; Nemoto, T.; Sugiyama, K.; Yokoyama, H. $\mathrm{CO}_{2}$ Foaming in Thin Films of Block Copolymer Containing Fluorinated Blocks. Macromolecules 2006, 39, 4746-4755.

(31) Spitael, P.; Macosko, C. W.; McClurg, R. B. Block Copolymer Micelles for Nucleation of Microcellular Thermoplastic Foams. Macromolecules 2004, 37, 6874-6882.

(32) Yokoyama, H.; Sugiyama, K. Nanocellular Structures in Block Copolymers with $\mathrm{CO}_{2}$-Philic Blocks Using $\mathrm{CO}_{2}$ as a Blowing Agent: Crossover from Micro-to Nanocellular Structures with Depressurization Temperature. Macromolecules 2005, 38, 10516-10522.

(33) Liu, S.; Zoetebier, B.; Hulsman, L.; Zhang, Y.; Duvigneau, J.; Vancso, G. J. Nanocellular Polymer Foams Nucleated by Core-Shell Nanoparticles. Polymer 2016, 104, 22-30.

(34) Lee, L. J.; Zeng, C.; Cao, X.; Han, X.; Shen, J.; Xu, G. Polymer Nanocomposite Foams. Compos. Sci. Technol. 2005, 65, 2344-2363.

(35) Ji, G.; Zhai, W.; Lin, D.; Ren, Q.; Zheng, W.; Jung, D. W. Microcellular Foaming of Poly(Lactic Acid)/Silica Nanocomposites in Compressed $\mathrm{CO}_{2}$ : Critical Influence of Crystallite Size on Cell Morphology and Foam Expansion. Ind. Eng. Chem. Res. 2013, 52, 6390-6398

(36) Rende, D.; Schadler, L. S.; Ozisik, R. Controlling Foam Morphology of Poly(Methyl Methacrylate) via Surface Chemistry and Concentration of Silica Nanoparticles and Supercritical Carbon Dioxide Process Parameters. J. Chem. 2013, 2013, 1-13.

(37) Zhai, W.; Yu, J.; Wu, L.; Ma, W.; He, J. Heterogeneous Nucleation Uniformizing Cell Size Distribution in Microcellular Nanocomposites Foams. Polymer 2006, 47, 7580-7589.

(38) Yuan, H.; Xiong, Y.; Luo, G.; Shen, Q.; Zhang, L. The Influence of In Situ Synthesized Nanoparticles on Microstructure and Compression Properties of Polymer Foams during Supercritical Carbon Dioxide Foaming. J. Appl. Polym. Sci. 2017, 134, 44629.
(39) Liberman, A.; Mendez, N.; Trogler, W. C.; Kummel, A. C. Synthesis and Surface Functionalization of Silica Nanoparticles for Nanomedicine. Surf. Sci. Rep. 2014, 69, 132-158.

(40) Bagwe, R. P.; Hilliard, L. R.; Tan, W. Surface Modification of Silica Nanoparticles to Reduce Aggregation and Nonspecific Binding. Langmuir 2006, 22, 4357-4362.

(41) Yang, J.; Sang, Y.; Chen, F.; Fei, Z.; Zhong, M. Synthesis of Silica Particles Grafted with Poly(Ionic Liquid) and Their Nucleation Effect on Microcellular Foaming of Polystyrene Using Supercritical Carbon Dioxide. J. Supercrit. Fluids 2012, 62, 197-203.

(42) Siripurapu, S.; DeSimone, J. M.; Khan, S. A.; Spontak, R. J. Low-Temperature, Surface-Mediated Foaming of Polymer Films. Adv. Mater. 2004, 16, 989-994.

(43) Goren, K.; Chen, L.; Schadler, L. S.; Ozisik, R. Influence of Nanoparticle Surface Chemistry and Size on Supercritical Carbon Dioxide Processed Nanocomposite Foam Morphology. J. Supercrit. Fluids 2010, 51, 420-427.

(44) Miller, M. B.; Luebke, D. R.; Enick, R. M. $\mathrm{CO}_{2}$-Philic Oligomers as Novel Solvents for $\mathrm{CO}_{2}$ Absorption. Energy Fuels 2010, $24,6214-6219$.

(45) Wang, H.; Li, W. Selective Ultrasonic Foaming of Polymer for Biomedical Applications. J. Manuf. Sci. Eng. 2008, 130, 021004.

(46) Liu, Q.; Zhu, Y.; Yang, G.; Yang, Q. Nucleation Thermodynamics inside Micro/Nanocavity. J. Mater. Sci. Technol. 2008, 24, 183-186.

(47) Qian, M.; Ma, J. The Characteristics of Heterogeneous Nucleation on Concave Surfaces and Implications for Directed Nucleation or Surface Activity by Surface Nanopatterning. J. Cryst. Growth 2012, 355, 73-77.

(48) Maksimov, A. O.; Kaverin, A. M.; Baidakov, V. G. Heterogeneous Vapor Bubble Nucleation on a Rough Surface. Langmuir 2013, 29, 3924-3934.

(49) Du, X.; Liu, X.; Chen, H.; He, J. Facile Fabrication of Raspberry-Like Composite Nanoparticles and Their Application as Building Blocks for Constructing Superhydrophilic Coatings. J. Phys. Chem. C 2009, 113, 9063-9070.

(50) Qian, Z.; Zhang, Z.; Song, L.; Liu, H. A Novel Approach to Raspberry-Like Particles for Superhydrophobic Materials. J. Mater. Chem. 2009, 19, 1297-1304.

(51) Du, X.; He, J. A Self-Templated Etching Route to SurfaceRough Silica Nanoparticles for Superhydrophobic Coatings. ACS Appl. Mater. Interfaces 2011, 3, 1269-1276.

(52) Li, D.; Zhu, Y.; Mao, C. One-Pot Synthesis of Surface Roughness Controlled Hollow Silica Spheres with Enhanced Drug Loading and Release Profiles under Ambient Conditions in Aqueous Solutions. J. Mater. Chem. B 2013, 1, 5515-5520.

(53) Tsai, H.-J.; Lee, Y.-L. Facile Method to Fabricate RaspberryLike Particulate Films for Superhydrophobic Surfaces. Langmuir 2007, 23, 12687-12692.

(54) Zakiyan, S. E.; Famili, M. H. N.; Ako, M. Controlling Foam Morphology of Polystyrene via Surface Chemistry, Size and Concentration of Nanosilica Particles. J. Mater. Sci. 2014, 49, $6225-6239$.

(55) Zhang, T.; Ge, J.; Hu, Y.; Zhang, Q.; Aloni, S.; Yin, Y. Formation of Hollow Silica Colloids through a Spontaneous Dissolution-Regrowth Process. Angew. Chem. 2008, 120, 5890-5895.

(56) Zhang, T.; Zhang, Q.; Ge, J.; Goebl, J.; Sun, M.; Yan, Y.; Liu, Y.-s.; Chang, C.; Guo, J.; Yin, Y. A Self-Templated Route to Hollow Silica Microspheres. J. Phys. Chem. C 2009, 113, 3168-3175.

(57) Musić, S.; Filipović-Vinceković, N.; Sekovanić, L. Precipitation of Amorphous $\mathrm{SiO}_{2}$ Particles and Their Properties. Braz. J. Chem. Eng. 2011, 28, 89-94.

(58) Kim, H.; Kim, H.-G.; Kim, S.; Kim, S. S. PDMS-Silica Composite Membranes with Silane Coupling for Propylene Separation. J. Membr. Sci. 2009, 344, 211-218.

(59) Liu, S.; Eijkelenkamp, R.; Duvigneau, J.; Vancso, G. J. SilicaAssisted Nucleation of Polymer Foam Cells with Nanoscopic Dimensions: Impact of Particle Size, Line Tension, and Surface Functionality. ACS Appl. Mater. Interfaces 2017, 9, 37929-37940. 
(60) Thommes, M. Physical Adsorption Characterization of Nanoporous Materials. Chem. Ing. Tech. 2010, 82, 1059-1073.

(61) Rouquerol, F. Adsorption by Powders and Porous Solids: Principles, Methodology and Applications; Academic Press: Kidlington, Oxford, 2014; pp 237-251.

(62) Thommes, M.; Cychosz, K. A. Physical Adsorption Characterization of Nanoporous Materials: Progress and Challenges. Adsorption 2014, 20, 233-250.

(63) Liu, S.; Pandey, A.; Duvigneau, J.; Vancso, J.; Snoeijer, J. H. Size-Dependent Submerging of Nanoparticles in Polymer Melts: Effect of Line Tension. Macromolecules 2018, 51, 2411-2417.

(64) Ally, J.; Molla, S.; Mostowfi, F. Condensation in Nanoporous Packed Beds. Langmuir 2016, 32, 4494-4499.

(65) Ullah, R.; Atilhan, M.; Diab, A.; Deniz, E.; Aparicio, S.; Yavuz, C. T. Synthesis, Characterization and Evaluation of Porous Polybenzimidazole Materials for $\mathrm{CO}_{2}$ Adsorption at High Pressures. Adsorption 2016, 22, 247-260.

(66) Jones, W.; Isaac, P.; Phillips, D. The Adsorption of Carbon Dioxide and Nitrogen at High Pressures by Porous Plugs of Lampblack. Trans. Faraday Soc. 1959, 55, 1953-1958.

(67) Fujiki, J.; Yamada, H.; Yogo, K. Enhanced Adsorption of Carbon Dioxide on Surface-Modified Mesoporous Silica-Supported Tetraethylenepentamine: Role of Surface Chemical Structure. Microporous Mesoporous Mater. 2015, 215, 76-83.

(68) Sanz-Pérez, E.; Arencibia, A.; Sanz, R.; Calleja, G. An Investigation of the Textural Properties of Mesostructured SilicaBased Adsorbents for Predicting $\mathrm{CO}_{2}$ Adsorption Capacity. RSC Adv. 2015, 5, 103147-103154.

(69) Fujiki, J.; Yogo, K. The Increased $\mathrm{CO}_{2}$ Adsorption Performance of Chitosan-Derived Activated Carbons with Nitrogen-Doping. Chem. Commun. 2016, 52, 186-189.

(70) Kumar, V.; Suh, N. P. A Process for Making Microcellular Thermoplastic Parts. Polym. Eng. Sci. 1990, 30, 1323-1329. 